\title{
Accelerating retreat and high-elevation thinning of glaciers in central Spitsbergen
}

\author{
Jakub Małecki \\ Cryosphere Research Department, Adam Mickiewicz University, Poznań, Poland \\ Correspondence to: Jakub Małecki (malecki.jk@gmail.com)
}

Received: 25 September 2015 - Published in The Cryosphere Discuss.: 6 November 2015

Revised: 2 June 2016 - Accepted: 13 June 2016 - Published: 24 June 2016

\begin{abstract}
Svalbard is a heavily glacier-covered archipelago in the Arctic. Dickson Land (DL), in the central part of the largest island, Spitsbergen, is relatively arid and, as a result, glaciers there are relatively small and restricted mostly to valleys and cirques. This study presents a comprehensive analysis of glacier changes in DL based on inventories compiled from topographic maps and digital elevation models for the Little Ice Age (LIA) maximum, the 1960s, 1990, and $2009 / 2011$. Total glacier area has decreased by $\sim 38 \%$ since the LIA maximum, and front retreat increased over the study period. Recently, most of the local glaciers have been consistently thinning in all elevation bands, in contrast to larger Svalbard ice masses which remain closer to balance. The mean 1990-2009/2011 geodetic mass balance of glaciers in DL is among the most negative from the Svalbard regional means known from the literature.
\end{abstract}

\section{Introduction}

Small glaciers are natural indicators of climate, as they record even slight oscillations via changes of their thickness, length, and area (Oerlemans, 2005). Twentieth century climate warming caused a volume loss of ice masses on a global scale (IPCC, 2013), contributing to about half of the recent rates of sea-level rise. Despite the relatively small area of glaciers and ice caps, their freshwater input to sea-level rise is of similar magnitude to that from the largest ice masses in the world: the Antarctic and Greenland ice sheets (Radic and Hock, 2011; Gardner et al., 2013). Therefore, it is of great importance to study the volume changes of all land ice masses in both hemispheres.
The archipelago of Svalbard is one of the most significant arctic repositories of terrestrial ice. Glaciers and ice caps cover $57 \%$ of the islands $\left(34 \times 10^{3} \mathrm{~km}^{2}\right)$ and have a total volume of $7 \times 10^{3} \mathrm{~km}^{3}$ (Nuth et al., 2013; Martín-Españyol et al., 2015). It is located in close proximity to the warm West Spitsbergen Current, and ice masses there are considered to be sensitive to changes in climate and ocean circulation (Hagen et al., 2003). The climate record suggests a sharp air temperature increase on Svalbard in the early 20th century, terminating the Little Ice Age (LIA) period around the 1920s (Hagen et al., 2003). A cooler period between the 1940s and 1960s was followed by a strongly positive summer temperature trend, i.e. $0.7^{\circ} \mathrm{C}$ decade $^{-1}$ for the period 1990 2010 (Førland et al., 2011; James et al., 2012; Nordli et al., 2014). Climate warming led to volume loss of the Svalbard glaciers (although with large spatial variability), particularly after 1990 (Hagen et al., 2003; Kohler et al., 2007; Sobota, 2007; Nuth et al., 2007, 2010, 2013; Moholdt et al., 2010; James et al., 2012).

Strong climatic gradients over the archipelago are an important factor modifying the response of Svalbard glaciers to climate change. Coastal zones receive the highest precipitation and experience low summer temperature and hence are heavily glacier-covered. In contrast, the interior of Spitsbergen, the largest island of the archipelago, receives relatively low amounts of precipitation due to its distance to the open ocean and to the surrounding rugged terrain of Svalbard; both factors act to limit moisture transport into the interior. As a result, this area has fewer and smaller glaciers than the adjoining areas. Lower snow amount means earlier exposure of low albedo surfaces and a more continental climate, with higher summer temperatures (Hagen et al., 1993; Nuth et al., 2013; Przybylak et al., 2014). The response of glaciers to 

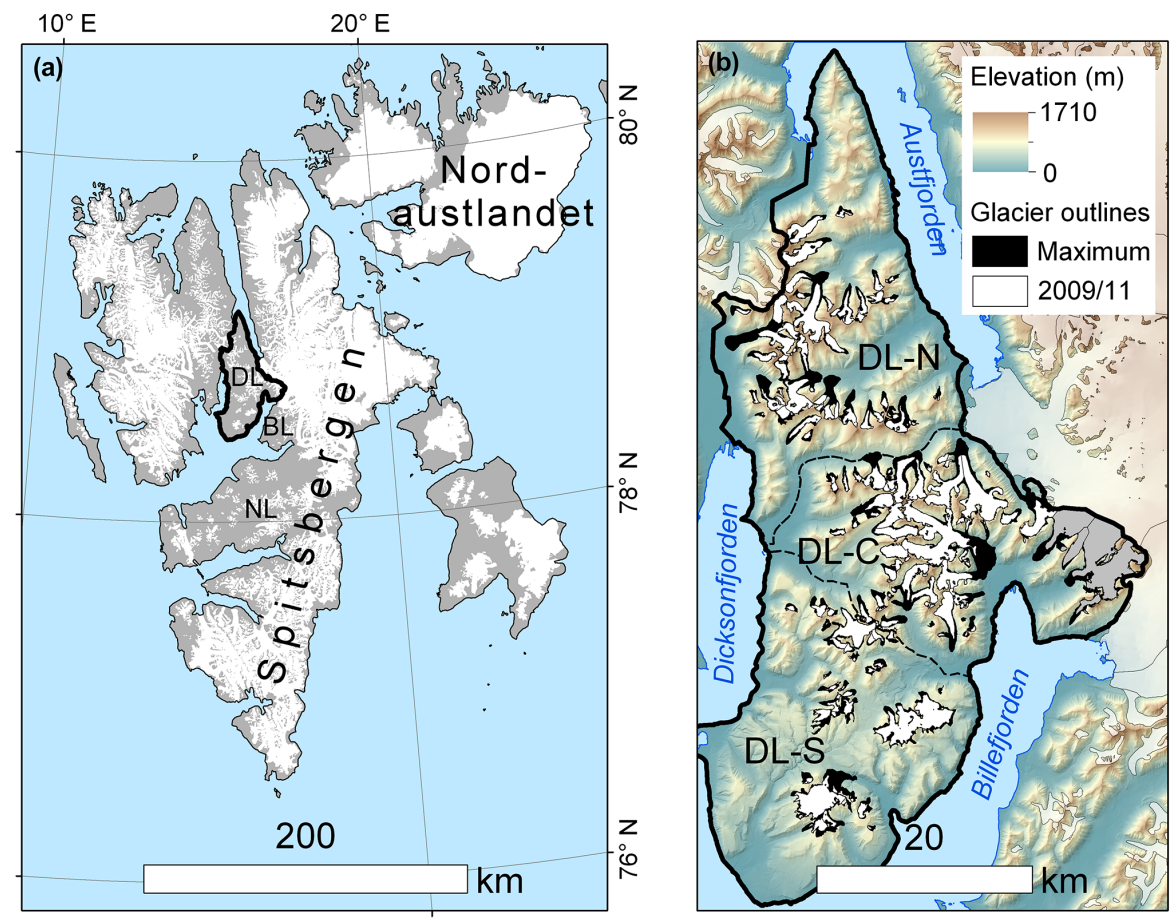

Figure 1. Location of the study area. (a) Map of Svalbard with locations of regions of central Spitsbergen: Dickson Land (DL), Nordenskiöld Land (NL), and Bünsow Land (BL). (b) Map of Dickson Land and its subregions: north (DL-N), central (DL-C), and south (DL-S). Glaciers coloured with grey in the eastern part of DL-C are not covered by 1990 digital elevation model.

climate change in these districts has been much more seldom studied, probably because of their presupposed low significance in the contribution to sea-level rise; small alpine glaciers are also difficult to study with satellite altimetry and regional mass balance models due to their complex relief. Detailed information on their spatiotemporal mass balance variability could, therefore, be used to test the Svalbard-wide modelling assessments. Moreover, research on the evolution of these small glaciers could be of practical interest, since they surround the main settlements of Svalbard. Their retreat may influence human activity, e.g. due to increased water and sediment delivery from glacier basins and associated consequences, such as floods and fjord bathymetry changes (Szczuciński et al., 2009; Rachlewicz, 2009a; Strzelecki et al., 2015a).

One of the regions situated the furthest from maritime influences (ca. $100 \mathrm{~km}$ ) is the sparsely glacier-covered Dickson Land (DL). This paper presents an inventory of the ice masses in DL and quantifies changes of their geometry since LIA termination. This includes changes of their area and length, as well as recent volume fluctuations, using digital elevation models (DEMs) obtained from aerial photogrammetry. The aim of this study is to investigate the response of glaciers in DL to climate change, with particular focus on their recent mass balance and its spatial variability.

\section{Study area}

The study region is located in central Spitsbergen and stretches between $78^{\circ} 27^{\prime} \mathrm{N}-79^{\circ} 10^{\prime} \mathrm{N}$ and $15^{\circ} 16^{\prime} \mathrm{E}-$ $17^{\circ} 07^{\prime} \mathrm{E}$. Its area is $1.48 \times 10^{3} \mathrm{~km}^{2}$ with a length of ca. $80 \mathrm{~km}$ in the north-south direction and a typical width of $20-30 \mathrm{~km}$. For the purpose of the glaciological analysis, DL was divided into three subregions - south (DL-S), central (DL-C), and north (DL-N) (Fig. 1). DL-S is the lowest elevated and is dominated by plateau-type mountains, with summits reaching 500-600 m a.s.l., occupied by small ice fields and ice masses plastered along gentle slopes. DL-C is the subregion with the greatest ice cover and the largest glaciers, mostly of valley type, and summits exceeding $1000 \mathrm{~m}$. The mountains in DL-N are even slightly higher than in the central part, but glaciers (mainly of valley and niche types) are smaller here and mostly oriented towards the north.

The climate of DL shows strong inner-fjord, quasicontinental characteristics, i.e. reduced precipitation and increased summer air temperature when compared to the coastal regions. The southernmost inlet of DL is located about $20 \mathrm{~km}$ north of Svalbard Lufthavn weather station (SVL, $15 \mathrm{~m}$ a.s.l.) near Longyearbyen. Between 1981 and 2010, the Norwegian Meteorological Institute recorded an average annual temperature of $-5.1^{\circ} \mathrm{C}$ at SVL, with the summer (June-August) mean of $4.9^{\circ} \mathrm{C}$. Annual measured precipitation was $188 \mathrm{~mm}$. In DL-C daily means of sea-level 
air temperature are very similar to those at SVL (Rachlewicz and Styszyńska, 2007; Láska et al., 2012). No meteorological stations are operating in DL-N, but the general climatic pattern suggests it is among the driest zones in all Svalbard (Hagen et al., 1993).

Previous glacial research performed in DL-C has focused mainly around the impact of glacier retreat on landscape evolution (e.g. Karczewski, 1989; Kostrzewski et al., 1989; Gibas et al., 2005; Rachlewicz et al., 2007; Rachlewicz, 2009a, b; Ewertowski et al., 2010, 2012; Ewertowski and Tomczyk, 2015; Evans et al., 2012; Szpikowski et al., 2014; Pleskot, 2015; Strzelecki et al., 2015a, b). More detailed glaciological investigations were performed on Bertilbreen (e.g. Žuravlev et al., 1983; Troicki, 1988) and recently also on Svenbreen (Małecki, 2013a, 2014, 2015). Glaciers in central and eastern parts of DL-C are losing their mass and their fronts are retreating (Rachlewicz et al., 2007; Małecki, 2013b; Małecki et al., 2013; Ewertowski, 2014). Glaciers of DL-N and DL-S have not been studied yet.

DL glaciers are mostly small, and only the largest $\left(>5 \mathrm{~km}^{2}\right)$ are partly warm based (Małecki, unpublished radar data). As a result, ice flow velocities are low; the maximum measured on the largest glaciers is less than $12 \mathrm{~m} \mathrm{a}^{-1}$ (Rachlewicz, 2009b), while on smaller glaciers it is several times lower (Małecki, 2014). In every subregion, however, surge-type glaciers are to be found. Studentbreen, the north-eastern outlet of Frostisen ice field, surged around 1930. Fyrisbreen advanced around 1960 (Hagen et al., 1993) and Hørbyebreen surged probably in the late 19th or early 20th century (Małecki et al., 2013). Also, 2009/2011 aerial imagery acquired by the Norwegian Polar Institute (available at toposvalbard.npolar.no) shows that the Hoegdalsbreen-Arbobreen, Manchesterbreen, and Vasskilbreen systems are characterized by deformed (looped) flow lines and/or moraines, which may indicate older surges.

\section{Data and methods}

\subsection{Glacier boundaries}

A ready-to-use Svalbard glacier inventory from the Norwegian Polar Institute (NPI) (König et al., 2013; Nuth et al., 2013) was evaluated as a potential data source for the purpose of this study. Due to the large Svalbard-wide scale of this work, some difficulties were met during preliminary geometry change analysis. Firstly, glaciers smaller than $1 \mathrm{~km}^{2}$ are not catalogued in the NPI glacier inventory. Secondly, polygons for the 2000s, particularly of the smallest ice patches, were too coarse to accurately reproduce their subtle decadal changes. Therefore, glacier inventories from this paper (covering glacier extents from Neoglacial maximum/LIA, 1960s, 1990, and 2009/2011) were prepared by the author using the original NPI source data, i.e. maps and modified ice and snow masks.
Glacier boundaries for the 1960s were manually digitized using ArcGIS software from scanned and georeferenced 1:100000 S100 series paper maps, constructed by NPI from 1:50000 aerial imagery taken between 1960 and 1966. The LIA area of glaciers was estimated by adding the area of their moraine zones to the 1960 s outlines, but no information was available for their lateral extent at that time. The 1990 outlines are based on the NPI glacier inventory (König et al., 2013; Nuth et al. 2013), but many polygons were added or modified according to the author's experience from the field to minimize errors of the final glacier area measurement. The most recent outlines were taken from the NPI database (available at data.npolar.no) as shapefiles based on 2009/2011 aerial photographs (Norwegian Polar Institute 2014a), which proved to be very accurate during direct field surveys.

Confluent glaciers of comparable size separated by a medial moraine were treated as individual units, except for Ebbabreen, the largest glacier in DL, which is historically considered as one object. Where possible, minor tributary glaciers, which eventually separated from the main stream, were fixed as individual glaciers in the earlier epochs as well, so area changes of a given glacier result from ice melt-out rather than from disconnection of former tributaries. Very small episodic snow fields and elongated snow patches connected with main glacier bodies were excluded from the inventory. Ice divides were fixed in time and did not account for changing ice topography. The small ice fields of Frostisen and Jotunfonna were not further divided into glacier basins.

\subsection{Digital elevation models}

As a 1990 and 2009/2011 topographic background for the analysis, $20 \mathrm{~m}$ DEMs from the NPI were used (Norwegian Polar Institute, 2014b). The 1990 DEM, which was constructed from 1:15000 aerial photographs, does not cover major glaciers in eastern DL-C, which comprise $17 \%$ of the modern glacier area of DL (Fig. 1b), so their elevation changes for the 1990-2009/2011 period could not be measured. Data for the most recent DEM originate from $0.5 \mathrm{~m}$ resolution aerial photographs, mainly from 2011, but the small eastern part of DL was covered by an earlier 2009 campaign. These data sources were projected into a common datum ETRS 1989 and fit onto a common grid. The universal co-registration procedure described by Nuth and Kääb (2011) was used to accurately align the datasets.

\subsection{Calculation of glacier geometry parameters and their changes}

From the modern boundaries and 2009/2011 DEM, the main morphometric characteristics of glaciers could be extracted. These were area $(A)$, length $(L)$, mean slope $(S)$, mean aspect $(\alpha)$, minimum, maximum, median, and moraine elevation ( $H_{\min }, H_{\max }, H_{\text {med }}$, and $H_{\text {mor }}$ respectively), and theo- 
retical steady-state equilibrium line altitude ( $t E L A)$, assuming an accumulation area ratio of 0.6. The area was measured for each polygon and epoch ( $A_{\max }, A_{1960}, A_{1990}$, and $A_{2011}$ respectively for each of the analysed epochs). $S, \alpha$, $H_{\text {min }}, H_{\text {max }}$, and $H_{\text {med }}$ were computed for each polygon for 2009/2011. $L$ was calculated for each epoch along the centrelines of the 66 largest valley, niche, and cirque glaciers, excluding irregular ice masses with no dominant flow direction, former minor tributary glaciers that used to share front with the main glacier in their basin, and very small glaciers with $A_{\max }<0.5 \mathrm{~km}^{2}$. On complex glaciers, e.g. with multiple outlets (e.g. Jotunfonna), more than one centerline had to be used to determine the representative lengths and retreat rates. Several parameters were used as indicators of glacier fluctuations, including area changes $(\mathrm{d} A)$, length changes $(\mathrm{d} L)$, volume changes over the period 1990-2009/2011 (dV), and mean elevation change for the period 1990-2009/2011 (dH), all also given as annual rates $(\mathrm{d} A / \mathrm{d} t, \mathrm{~d} L / \mathrm{d} t, \mathrm{~d} V / \mathrm{d} t$, and $\mathrm{d} H / \mathrm{d} t$ respectively). All rates of glacier change indicators were computed according to the year of validity of geometry data.

To compute $\mathrm{d} V$, elevation change pixel grids were first calculated for each ice mass by subtracting the 1990 DEM from the 2009/2011 DEM. This is an accurate method for determining mass change (Cox and March, 2004), providing information about thickness changes over the entire glacier with no need for extrapolation of mass balance values from single reference points, as is the case with stakes used in the direct glaciological method. The arithmetic average of elevation change pixels lying within the larger (here 1990) glacier boundary $(\overline{\mathrm{d} h})$ was then used to compute $\mathrm{d} V$ using Eq. (1).

$\mathrm{d} V=\overline{\mathrm{d} h} \times A_{1990}$.

The mean elevation change of glaciers, $\mathrm{d} H$, was inferred by dividing $\mathrm{d} V$ by the average area of a glacier over the period 1990-2009/2011 to account for its retreat (Eq. 2).

$\mathrm{d} H=\frac{2 \mathrm{~d} V}{\left(A_{1990}+A_{2011}\right)}$.

Near-surface glacier density changes were not considered in the conversion of the geodetic mass balance to water equivalent (w.e.), as they were assumed to be small when compared to climatically induced elevation changes over the study period 1990-2009/2011. This assumption is more uncertain in the highest zones of glaciers, where changes in firn thickness may lead to considerable density variations. However, direct field surveys and analysis of the available satellite images indicate that in the late summer the highest glacier zones in DL are usually composed of glacier ice or superimposed ice and almost no firn is present. Moreover, Kohler et al. (2007) found a good match between the geodetic and glaciologically measured cumulative mass balance on a small NW Spitsbergen glacier, implying density changes may be neglected in geodetic balance calculations on comparatively small and retreating ice masses in Svalbard. Therefore, $\mathrm{d} H / \mathrm{d} t$ could be

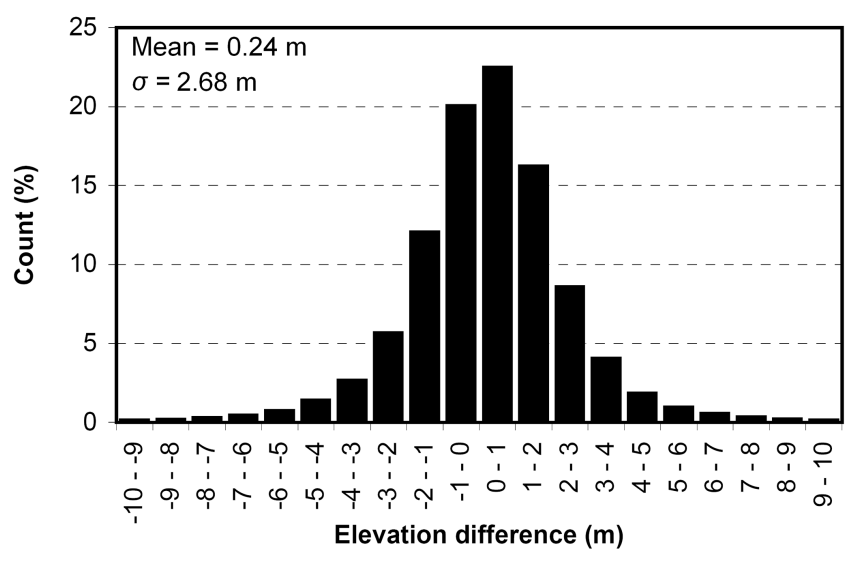

Figure 2. Histogram of elevation differences between 2009/2011 DEM and 1990 DEM over non-glacier-covered terrain.

converted to water equivalent by multiplication by an average ice density of $900 \mathrm{~kg} \mathrm{~m}^{-3}$.

\subsection{Errors}

Glacier area measurements for the 1960s epoch suffer from errors associated with general map accuracy or misinterpretations made by cartographers, e.g. due to the considerable extent of winter snow cover on aerial images. To account for that, $25 \mathrm{~m}$ was used as a horizontal glacier polygon digitalizing error. Each polygon was assigned a $25 \mathrm{~m}$ buffer with "-" and "+" signs. Including these buffers, new areas of DL glaciers were computed and compared to all original polygons. Differences between the new and original values were used as an error estimate of $A_{1960}$ for each glacier, with $\pm 6.4 \%$ as a region-wide total, which was larger for the smaller ice masses. Since no maps are available for the LIA maximum, LIA glacier area estimation is based on the 1960s outlines and geomorphological mapping of moraine zones. Such an approach assumes only frontal retreat in the period LIA-1960s, but some lateral retreat most likely took place as well. Also, moraine deposits of some glaciers could have either been eroded before the aerial photogrammetry era or not formed at all. Application of a relatively large $\pm 50 \mathrm{~m}$ buffer around the LIA outlines resulted in a total glacier area error estimate of $\pm 11.5 \%$ for that epoch. For 1990 and 2009/2011 epochs lower buffers of $\pm 10 \mathrm{~m}$ and $\pm 5 \mathrm{~m}$ were used, resulting in glacier area uncertainty estimates of \pm 3.4 and $\pm 2.2 \%$ for the whole DL region. Uncertainties of length measurement for each year were set according to the buffers described above.

To estimate the error of $\overline{\mathrm{d} h}(\varepsilon)$, elevation differences between the 1990 and 2009/2011 DEMs over non-glaciercovered terrain in the whole study region were measured. Since glacier surface slopes in DL are relatively gentle, mountain slopes steeper than $20^{\circ}$ were excluded from the analysis. The results show that an elevation difference of 

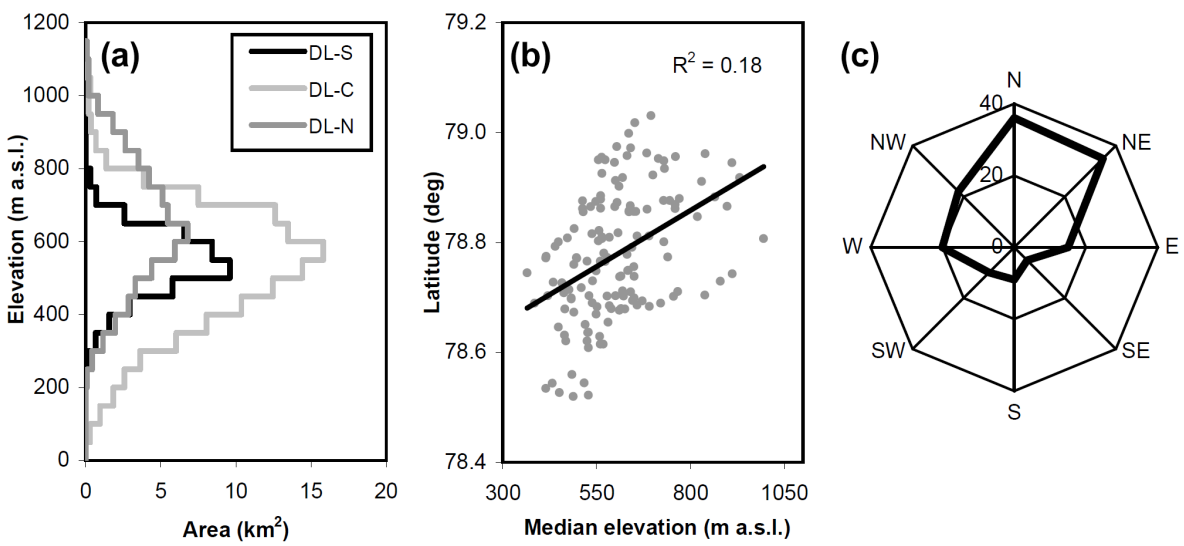

Figure 3. Main features of the modern glacier geometry in DL: area-altitude distribution (a), scatter plot of latitude against median glacier elevations (b), and frequency distribution of mean glacier aspects (c).

over $70 \%$ of pixels is within $\pm 2 \mathrm{~m}$ and less than $5 \%$ are characterized by an elevation difference of more than $\pm 5 \mathrm{~m}$ (Fig. 2). The mean elevation difference between the two DEMs was $0.24 \mathrm{~m}$, a correction further subtracted from all obtained $\overline{\mathrm{d} h}$ values, while the standard deviation, $\sigma$, was $2.68 \mathrm{~m}$. Here, $\sigma$ is used as a point elevation difference uncertainty and is further used to compute $\varepsilon$ for individual glaciers. The elevation measurement error of snow-covered surfaces was, however, expected to be larger than for rocks and vegetated areas due to its lower radiometric contrast on aerial images. To account for this effect, parts of glacier surfaces extending above $550 \mathrm{~m}$ a.s.l. (an approximate snow line on 1990 and 2009/2011 aerial imagery) have a prescribed error characteristic of $2 \sigma$. For each glacier, $\varepsilon$ was then calculated using Eq. (3):

$\varepsilon=\frac{[(1-n) \cdot \sigma]+(n \cdot 2 \sigma)}{\sqrt{N}}$,

where $n$ is the fraction of the glacier extending above $550 \mathrm{~m}$ and $N$ is the sample size. Assuming spatial autocorrelation of elevation errors at an order of $1000 \mathrm{~m}$ after Nuth et al. (2007), $N$ becomes glacier size in $\mathrm{km}^{2}$ rather than number of sample points. Using $\varepsilon$ and errors of glacier area measurements, uncertainties of $\mathrm{d} V$ and $\mathrm{d} H$ could be assessed with conventional error propagation methods. All errors are relatively large for the smallest ice masses and vice versa.

\section{Results}

\subsection{Modern geometry of Dickson Land glaciers}

In the most recent 2009/2011 inventory 152 ice masses were catalogued in DL, all terminating on land and covering a total of $207.4 \pm 4.6 \mathrm{~km}^{2}$ ( $14 \%$ of the region). 110 ice masses ( $72 \%$ of the population) have areas $<1 \mathrm{~km}^{2}$ and 86 of these are smaller than $0.5 \mathrm{~km}^{2}$. Only nine glaciers $(6 \%)$ are larger than $5 \mathrm{~km}^{2}$. The largest glaciers are Ebbabreen $\left(24.3 \mathrm{~km}^{2}\right)$,
Cambridgebreen-Baliollbreen system $\left(16.3 \mathrm{~km}^{2}\right)$, Hørbyebreen system $\left(15.9 \mathrm{~km}^{2}\right)$, and Jotunfonna $\left(14.0 \mathrm{~km}^{2}\right)$. Northfacing glaciers $(\mathrm{N}, \mathrm{NW}$, and NE) comprise $61 \%$ of the population, while only $16 \%$ of ice masses have a southern aspect ( $\mathrm{S}, \mathrm{SW}$, and $\mathrm{SE}$ ). The mean glacier slope is $10.7^{\circ}$.

DL-C is the subregion with the greatest glacier coverage $\left(26 \%\right.$ or $\left.117 \mathrm{~km}^{2}\right)$, compared to only $8 \%\left(39 \mathrm{~km}^{2}\right)$ and $10 \%\left(51 \mathrm{~km}^{2}\right)$ in DL-S and DL-N, respectively. The subregions also differ significantly in their area-altitude distribution. Glacier maximum and median elevation increases moving from south to north. DL-N contains most of the highelevation glacier area in DL, with a median elevation of $614 \mathrm{~m}$. In DL-C, glacier fronts reach the lowest elevations, while the glacier hypsometry of DL-S is the flattest and contains the lowest fraction of high-elevation areas. The median elevation of the two latter subregions is $520 \mathrm{~m}$, giving an overall median elevation of glaciers in DL of $539 \mathrm{~m}$ and a $t E L A$ of $504 \mathrm{~m}$ a.s.l. The total volume of DL ice masses, estimated with empirical area-volume scaling parameters by Martín-Español et al. (2015), is roughly $12 \mathrm{~km}^{3}$. The main details of glacier geometry characteristics are depicted in Fig. 3.

\subsection{Glacier area and length reduction}

Since the termination of the LIA, the glaciers of DL have been continuously losing area, in total by $38 \pm 12 \%$ (Fig. 4a; Table 1). The overall rate of area loss was $0.49 \pm 0.66 \mathrm{~km}^{2} \mathrm{a}^{-1}$ in the first epoch, which increased 4-fold to $2.01 \pm 0.85 \mathrm{~km}^{2} \mathrm{a}^{-1}$ after 1960 and further to $2.23 \pm 0.48 \mathrm{~km}^{2} \mathrm{a}^{-1}$ after 1990 (Fig. 4a). Excluding known and probable surge-type glaciers, whose areal extent can change due to internal dynamic instability rather than in direct response to climate, shows that increasing area loss rates are related to climate forcing rather than to ice dynamics (Fig. 4b). The larger error bars of $\mathrm{d} A / \mathrm{d} t$ preclude identification of any trends in that signal. 
Table 1. Changing extent of glaciers in Dickson Land over the study periods.

\begin{tabular}{|c|c|c|c|c|c|c|c|c|c|}
\hline \multirow[t]{2}{*}{ Subregion } & \multicolumn{4}{|c|}{ Area, $A\left(\mathrm{~km}^{2}\right)$} & \multicolumn{2}{|l|}{ Area change, $\mathrm{d} A$} & \multicolumn{3}{|c|}{ Length change rates, $\mathrm{d} L / \mathrm{d} t\left(\mathrm{~m} \mathrm{a}^{-1}\right)$} \\
\hline & Max & $1960 \mathrm{~s}$ & 1990 & $2009 / 2011$ & Max-2009/2011 & Max-1960s & $1960 s-1990$ & $1990-2009 / 2011$ & Max-2009/2011 \\
\hline DL-N & $91.8 \pm 12.0$ & $78.6 \pm 3.3$ & $63.8 \pm 2.7$ & $51.0 \pm 1.4$ & $-44.4 \pm 14.4 \%$ & $-6.3 \pm 0.2$ & $-10.4 \pm 0.2$ & $-18.3 \pm 0.1$ & $-9.5 \pm 0.1$ \\
\hline DL-C & $174.9 \pm 18.1$ & $159.6 \pm 11.8$ & $137.9 \pm 4.1$ & $117.1 \pm 2.2$ & $-33.1 \pm 11.0 \%$ & $-4.7 \pm 0.2$ & $-10.1 \pm 0.2$ & $-18.1 \pm 0.1$ & $-8.4 \pm 0.1$ \\
\hline DL-S & $67.4 \pm 8.3$ & $64.0 \pm 4.2$ & $50.3 \pm 1.7$ & $39.3 \pm 0.9$ & $-41.7 \pm 13.3 \%$ & $-3.0 \pm 0.2$ & $-6.5 \pm 0.3$ & $-10.4 \pm 0.1$ & $-5.3 \pm 0.1$ \\
\hline Total & $334.1 \pm 38.4$ & $302.2 \pm 19.3$ & $252.0 \pm 8.6$ & $207.4 \pm 4.6$ & $-37.9 \pm 12.1 \%$ & $-4.9 \pm 0.1$ & $-9.4 \pm 0.1$ & $-16.4 \pm 0.1$ & $-8.1 \pm 0.1$ \\
\hline
\end{tabular}

Table 2. Volume changes, elevation changes, and mass balance of glaciers in subregions of Dickson Land over the period 1990-2009/2011.

\begin{tabular}{llllll}
\hline Subregion & $\begin{array}{l}\mathrm{d} V \\
\left(\text { millions } \mathrm{m}^{3}\right)\end{array}$ & $\begin{array}{l}\mathrm{d} V / \mathrm{d} t \\
\left(\text { millions } \mathrm{m}^{3} \mathrm{a}^{-1}\right)\end{array}$ & $\begin{array}{l}\mathrm{d} H \\
(\mathrm{~m})\end{array}$ & $\begin{array}{l}\mathrm{d} H / \mathrm{d} t \\
\left(\mathrm{~m} \mathrm{a}^{-1}\right)\end{array}$ & $\begin{array}{l}\text { Specific mass balance } \\
(\mathrm{m} \text { w.e. })\end{array}$ \\
\hline DL-N & $-735 \pm 46$ & $-35.0 \pm 2.3$ & $-12.8 \pm 1.1$ & $-0.61 \pm 0.05$ & $-0.55 \pm 0.04$ \\
DL-C $^{*}$ & $-1482 \pm 67$ & $-70.6 \pm 3.3$ & $-16.6 \pm 1.2$ & $-0.79 \pm 0.06$ & $-0.71 \pm 0.05$ \\
DL-S $^{*}$ & $-651 \pm 37$ & $-31.0 \pm 1.8$ & $-14.5 \pm 1.2$ & $-0.69 \pm 0.06$ & $-0.62 \pm 0.05$ \\
Total $^{*}$ & $-2867 \pm 116$ & $-136.5 \pm 5.7$ & $-15.0 \pm 1.0$ & $-0.71 \pm 0.05$ & $-0.64 \pm 0.05$ \\
\hline
\end{tabular}

* Excluding glaciers in eastern DL-C due to the lack of 1990 DEM coverage.

In contrast to $\mathrm{d} A / \mathrm{d} t$, average length change rates $\mathrm{d} L / \mathrm{d} t$ have smaller uncertainties. From the available temporal resolution of the data no front advances were detected, although the surge events of Frostisen and Fyrisbreen occurred in the first period (Hagen et al., 1993). In general, all glaciers have been retreating since the LIA termination and the extremes of total $\mathrm{d} L$ observed in DL were -46 and $-3325 \mathrm{~m}$. Epochs LIA-1960s and 1960s-1990 were the periods with the fastest retreat for only $26 \%$ of the study glaciers. In many of the latter cases, bedrock topography supported a short-term increase in $\mathrm{d} L / \mathrm{d} t$, e.g. due to rock sills dissecting thinning glacier snouts into active and dead ice zones (e.g. Ebbabreen, Frostisen, Svenbreen). The vast majority of glaciers (74\%) were retreating at their fastest rate in the last study period 1990-2009/2011.

\subsection{Glacier thinning and mass balance}

A strikingly negative and consistent elevation change pattern is evident from the 1990-2009/2011 data, including in the highest zones of glaciers all over DL (Figs. 5 and 6). At the lowest altitudes $(<200 \mathrm{~m}$ a.s.1.), the mean change rate was ca. $-2 \mathrm{ma}^{-1}$, while at the average $t E L A$ (ca. $500 \mathrm{~m}$ a.s.1.) this was about $-0.6 \mathrm{~m} \mathrm{a}^{-1}$. Positive fluctuations were observed above ca. 1000 ma.s.l., mostly in DL-N. Some glaciers have been thinning at a very high average rate, exceeding $1 \mathrm{ma}^{-1}$, while only a few small ice patches have been closer to balance. Overall, the average area-weighted $\mathrm{d} H / \mathrm{d} t$ in DL was highly negative at $-0.71 \pm 0.05 \mathrm{~m} \mathrm{a}^{-1}\left(-0.64 \pm 0.05 \mathrm{~m}\right.$ w.e. $\left.\mathrm{a}^{-1}\right)$, resulting in a total volume loss rate of $137 \pm 6 \times 10^{6} \mathrm{~m}^{3} \mathrm{a}^{-1}$ and a mass balance of $-0.12 \pm 0.01 \mathrm{Gt} \mathrm{a}^{-1}$ (excluding major glaciers in eastern DL-C due to the lack of 1990 DEM coverage). Subregional values are given in Table 2 and indicate that the most negative specific mass balances are found in DL-C and the least negative in DL-N.

\subsection{Links between glacier change indicators and their geometry}

Recent thinning rates decrease with altitude, so the highestelevation glaciers, mainly in DL-N, have been thinning the least, while glaciers with a large portion of low-elevation ice (e.g. as in DL-C) had the fastest thinning rates (Fig. 7a). Length changes are correlated with terminus altitude and glacier length, so low-elevation fronts of long glaciers have been retreating at the fastest rates. Relative area change was best correlated with relative length change (Fig. 7b), glacier area, maximum elevation, and length, so large glaciers lost the smallest fraction of their maximum extent despite significant absolute area and length losses. In contrast to reports from many other regions of the globe (e.g. $\mathrm{Li}$ and $\mathrm{Li}$, 2014; Fischer et al., 2015; Paul and Mölg, 2014), glacier aspect showed no statistical correlation with any of the glacier change parameters, which may result from the summertime midnight sun over Svalbard and the more balanced insolation on slopes with northern and southern aspects, compared to midlatitudes. Pearson correlation coefficients of glacier change parameters against other parameters and glacier geometry variables are given in Table 3 .

\section{Discussion}

In agreement with earlier studies from Svalbard (Kohler et al., 2007; Nuth et al., 2007, 2010, 2013; James et al., 2012), climate warming is anticipated to be the main control for the observed negative glacier changes in DL. Air temperature at the nearest meteorological station, SVL, clearly increased in the 1920s and 1930s, as well as after 1990 (Nordli et al., 

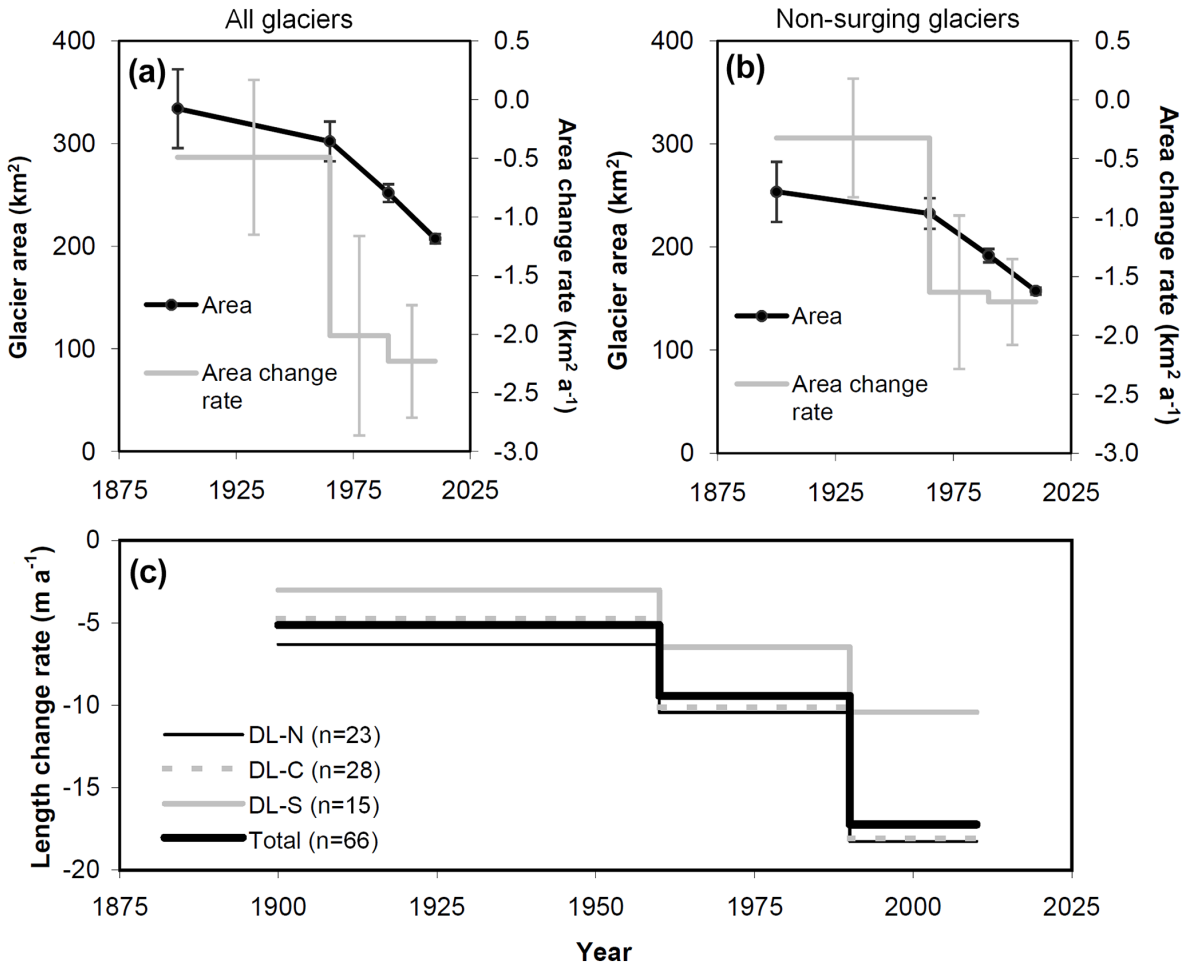

Figure 4. (a) Changes of the total glacier area in Dickson Land. (b) Same as (a) but for non-surging glaciers only. (c) Average glacier length change rates in Dickson Land and its subregions.

2014), which explains the glacier retreat after the LIA maximum and in the last study epoch, respectively. However, the clear post-1960 mass loss acceleration of DL glaciers may not simply be explained by increased air temperature. In the period 1960-1990 the total glacier area loss rate quadrupled (although with large uncertainty) and front retreat rates doubled, despite the fact that the mean multi-decadal summer air temperature was very similar to that in the first epoch and no decrease in winter snow accumulation over Svalbard was evident at that time (Pohjola et al., 2002; Hagen et al., 2003). In this context, it seems likely that average summer air temperature is not the only driver of change for small, low-activity glaciers in DL and other factors may also play a role. These could be, for example, different response times of glaciers or albedo feedbacks, which could modify glacier mass balance in a nonlinear pattern, e.g. by removal of high-albedo firn from accumulation zones, and hence increase energy absorption (Kohler et al., 2007; James et al., 2012, Małecki 2013b).

For the majority of glaciers in DL, the post-1990 period was marked by their fastest multi-decadal front retreat rates since the LIA maximum. This trend is similar to that on many land-terminating glaciers of Svalbard (Jania, 1988; Lankauf, 2007; Zagórski et al., 2008; James et al., 2012; Nuth et al., 2013) (Fig. 3). Length reduction was the main driver for glacier area decrease (Fig. 7b), which was high in DL and amounted to $38 \%$, supporting previous conclusions by $\mathrm{Zi}-$ aja (2001) and Nuth et al. (2013) that central Spitsbergen, with its much smaller glaciers, is losing its ice cover extent at a relatively higher rate than maritime regions of Svalbard (e.g. $18 \%$ area decrease in Sørkapp Land, 1936-1991; reported by Ziaja, 2001). Area loss rates in DL were at a similar level between 1960s-1990 and 1990-2009/2011, comparable to the results in Nuth et al. (2013), who concluded that there was no clear trend of $\mathrm{d} A / \mathrm{d} t$ evolution over the archipelago except for southern Spitsbergen, where area loss rates generally decreased after 1990. In contrast, Błaszczyk et al. (2013) concluded that there were increasing area loss rates for tidewater glaciers in Hornsund, part of south Spitsbergen. Interestingly, ca. $800 \mathrm{~km}^{2}$ of glaciers in Hornsund, often considered to be among the most sensitive to climate warming, have been losing area at a rate comparable to ca. $200 \mathrm{~km}^{2}$ of small glaciers in DL (ca. $1 \mathrm{~km}^{2} \mathrm{a}^{-1}$ for the period LIA-2000s).

Clear acceleration of length loss rates indicates that glaciers in DL have been experiencing an increasingly negative mass balance since the termination of the LIA. This is in line with earlier studies. For seven glaciers in DL-C, Małecki (2013b) documented mean $\mathrm{d} H / \mathrm{d} t$ of $-0.49 \mathrm{~m} \mathrm{a}^{-1}$ for the period 1960s-1990, followed by an acceleration of mass loss rate to $-0.78 \mathrm{ma}^{-1}$ after 1990 . Kohler et al. (2007) analysed $\mathrm{d} H / \mathrm{d} t$ of two small land-terminating glaciers in Spitsbergen with greater temporal resolution than that available for this study and concluded there was a continuous acceleration of their thinning over the 20th 

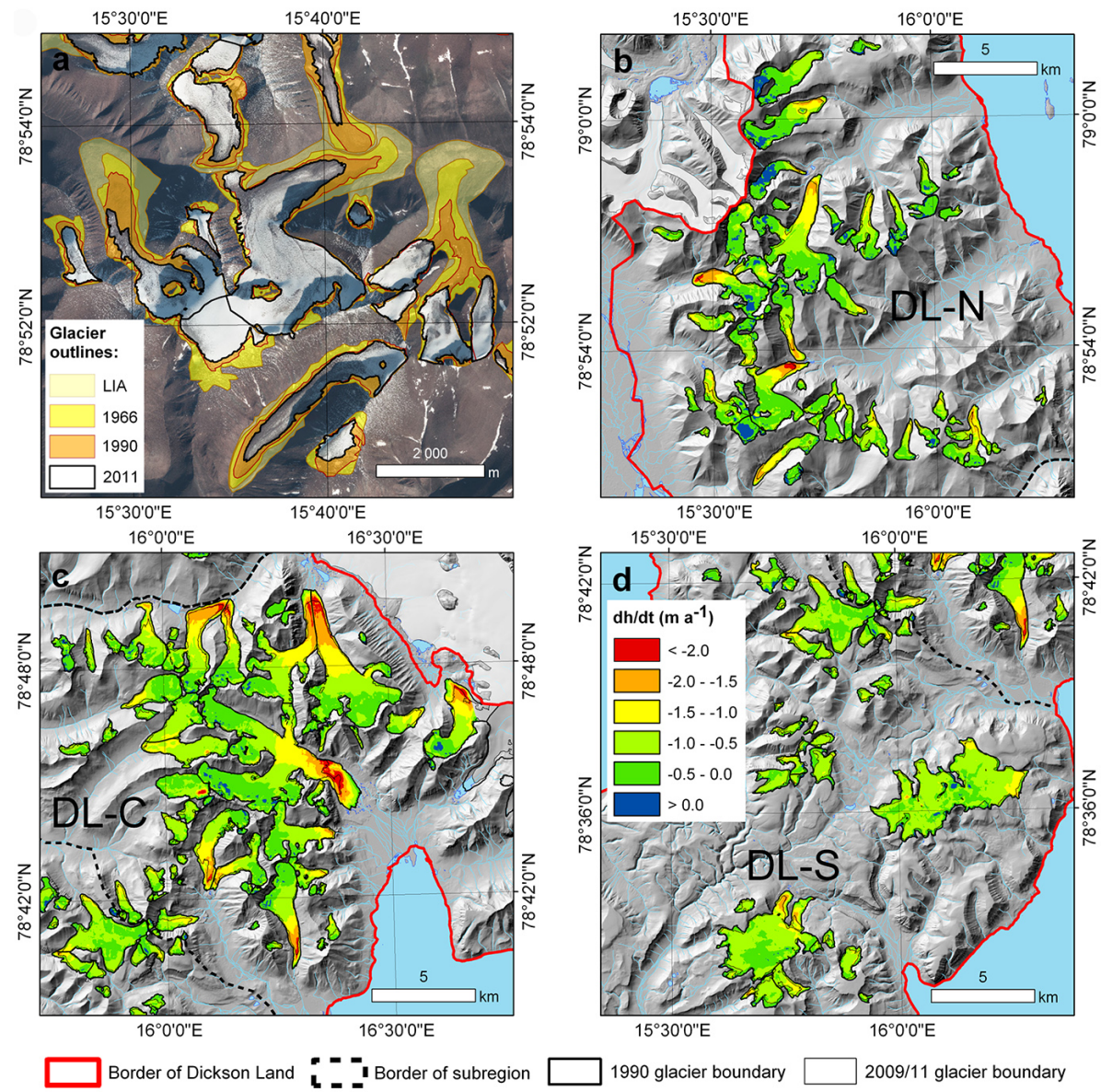

Figure 5. An example of glacier area changes in northern Dickson Land in the Vasskilbreen region (a); the mean 1990-2009/2011 elevation change rates in northern (b), central (c), and southern (d) Dickson Land. Orthophotomap for (a) ${ }^{\odot}$ Norwegian Polar Institute.
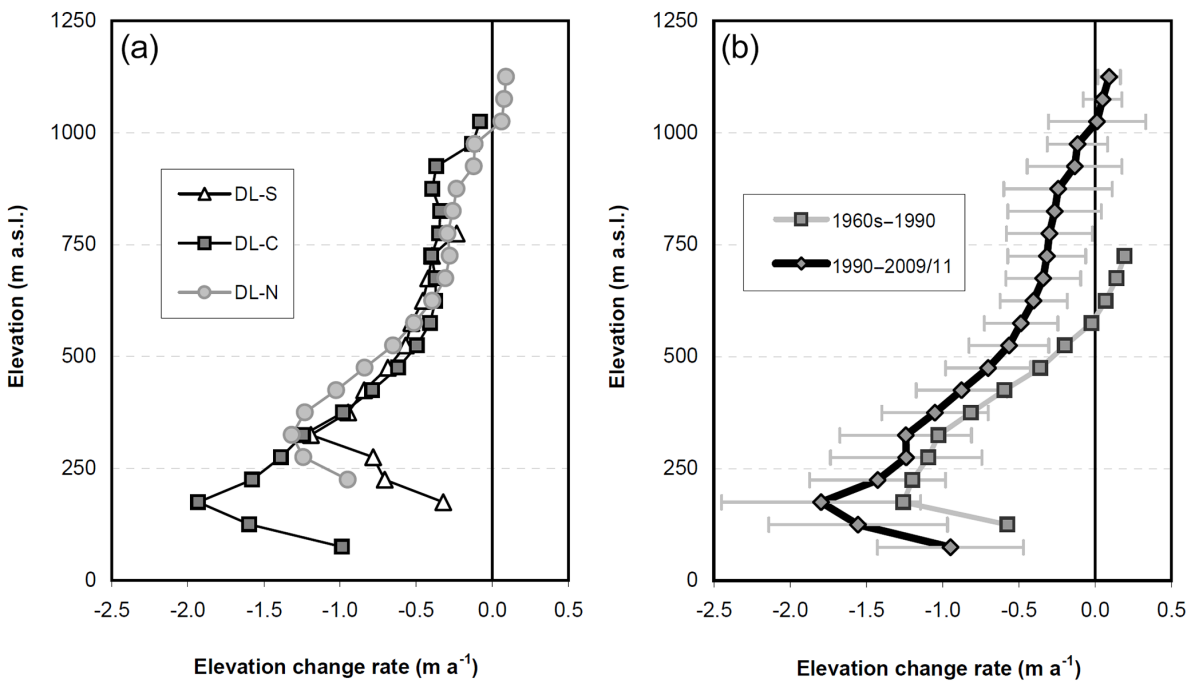

Figure 6. Homogeneity of the (a) 1990-2009/2011 elevation change pattern in DL subregions. (b) The mean pre-1990 and post-1990 elevation change rates in DL averaged from the available data. Horizontal bars represent 1 standard deviation. The 1960 s-1990 data are compiled from Małecki (2013b) and Małecki et al. (2013). 

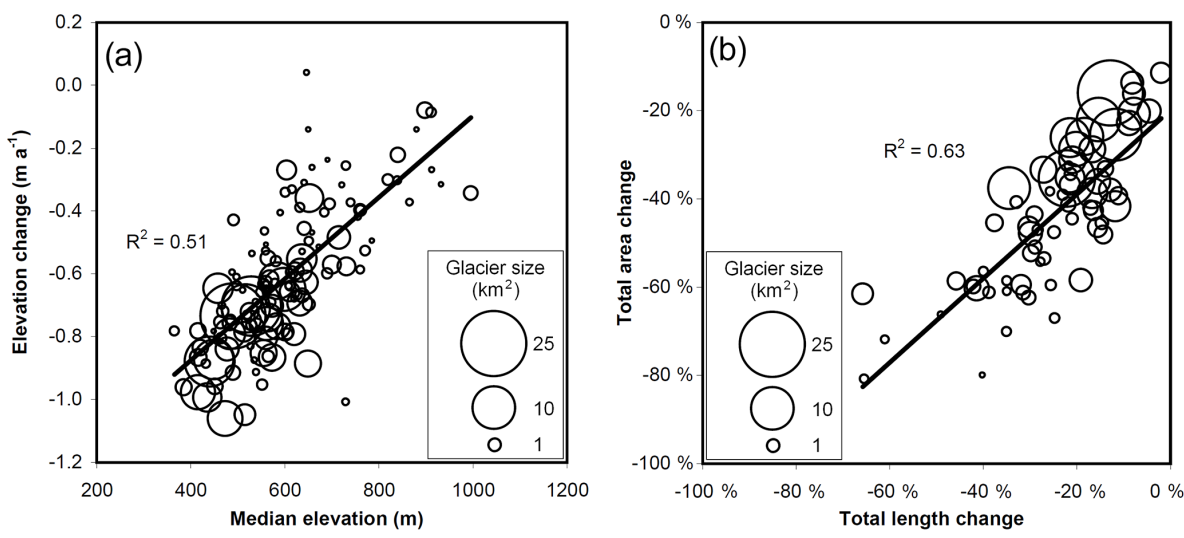

Figure 7. Scatter plots showing the relationship between mean 1990-2009/2011 glacier elevation change and median elevation of glaciers (a) and total area change and total length change of glaciers (b).

century, e.g. from $\mathrm{d} H / \mathrm{d} t=-0.15 \mathrm{ma}^{-1}$ (1936-1962) to $\mathrm{d} H / \mathrm{d} t=-0.69 \mathrm{~m} \mathrm{a}^{-1}(2003-2005)$ for Midre Lovénbreen in NW Spitsbergen. James et al. (2012) documented negative $\mathrm{d} H / \mathrm{d} t$ for six small land-terminating glaciers all over Svalbard since at least the 1960s and reported a post-1990 increase in mass loss rates for four of these. Their recent $\mathrm{d} H / \mathrm{d} t$ ranged from -0.28 to $-1.21 \mathrm{~m} \mathrm{a}^{-1}$, i.e. similar to the values observed in DL.

An important finding of this study is the observation of glacier-wide thinning over DL up to an elevation of 1000 m a.s.l., where the average 1990-2009/2011 zero elevation change line was found. To put this into historical context, previous analyses performed for the earlier period 1960s-1990 identified this threshold at a much lower average altitude, i.e. at ca. $600 \mathrm{~m}$ a.s.l. in DL-C (Małecki, 2013b; Małecki et al., 2013) (Fig. 6). The shift of the geodetic equilibrium suggests a recent negative change in glacier mass balance, including former accumulation zones. This hypothesis is supported by direct records (2011-2015) from Svenbreen (DL-C), where negative surface mass balance has also been noted at the highest ablation stake ( $625 \mathrm{~m}$ a.s.l.) near the glacier headwalls (Małecki, unpublished data). On Nordenskiöldbreen, a large tidewater glacier neighbouring DL from the east, mean 1989-2010 ELA, was modelled at $719 \mathrm{~m}$ a.s.l., i.e. higher than the accumulation zones of most DL glaciers (Van Pelt et al., 2012).

Thinning at the high elevations of the study glaciers could be linked to several factors. Firstly, there is the increased melt energy availability due to (i) increased incoming longwave radiation from the atmosphere and turbulent heat fluxes resulting from post-1990 summer air temperature rise; (ii) increased energy absorption by the ice surface due to decreasing albedo caused by firn melt-out, dust, or sediment delivery from freshly exposed headwalls; and (iii) increased longwave emission from surrounding slopes recently uncovered from snow and ice. Other possible explanations are related to firn evolution, i.e. its compaction or melt-out, supporting the re- duction of internal meltwater refreezing. The last probable mechanism could be a recent snow accumulation decrease. Data availability on winter mass balance in DL are insufficient for such conclusions (Troicki, 1988; Małecki, 2015), but the trend for a snow precipitation decrease after 1990 has been noted for SVL (James et al., 2012). Glacier dynamics could also explain changes in the glaciers' upper zones, but there are too few data to test this idea. However, low flow velocities of DL glaciers $\left(1-10 \mathrm{~m} \mathrm{a}^{-1}\right)$ suggest the minimal importance of the dynamic component in their surface elevation changes.

High-elevation glacier thinning in DL will have important consequences for the local cryosphere. Surge-type glaciers will not build up towards new surges and as such could be removed from the surge cycle under present climate conditions, as demonstrated in more detail for Hørbyebreen by Małecki et al. (2013). This will also lead to decay of temperate ice zones, still found beneath the largest glaciers of DL (Małecki, unpublished data), and consequently it will influence their hydrology and geomorphological activity and reduce ice flow dynamics, as documented for other small glaciers in central Spitsbergen (Hodgkins et al., 1999; Lovell et al., 2015). Eventually, given that the highest parts of glaciers in DL typically reach 700-800 m a.s.l., the high altitude of the recent geodetic equilibrium suggests their considerable or complete melt-out in the future, even if the atmospheric warming trend stops. Notably, altitude had the strongest influence on the spatial mass balance variability (Figs. 6 and 7a), so small low-elevation glaciers were the most sensitive to climate shift. They had the fastest front retreat rates and the most negative $\mathrm{d} H / \mathrm{d} t$ (Fig. 7a); hence, they are likely to be the first to disappear.

Glacier-wide surface lowering has already been triggered in some of the world's largest ice repositories, including the Canadian Arctic Archipelago (Gardner et al., 2011) and Patagonian ice fields (Willis et al., 2012), causing them to significantly contribute to sea-level rise. In Svalbard, the ma- 


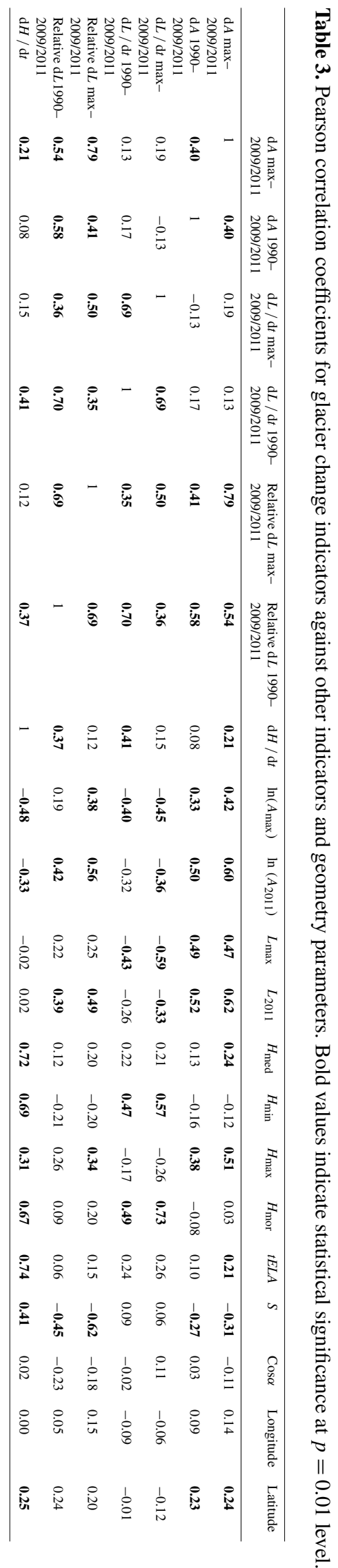

jor ice masses are still building up their higher zones and remain closer to balance (Moholdt et al., 2010; Nuth et al., 2010), but the process of high-elevation thinning seems to be already widespread on smaller glaciers across the archipelago, as documented by Kohler et al. (2007), James et al. (2012), and this study. By the end of the 21 st century, a further $3-8^{\circ} \mathrm{C}$ warming over Svalbard is predicted by climate models (Førland et al., 2011; Lang et al., 2015). This will eventually cause the complete decay of the accumulation zones of Svalbard ice masses, boosting their mass loss rates and the sea-level rise contribution from the region. Small Spitsbergen glaciers may, therefore, be perceived as an early indicator of the future changes of larger ice caps and ice fields.

The mass balance of glaciers in central Spitsbergen has been previously considered by some researchers to be relatively resistant to climate change due to the prevailing dry conditions and high hypsometry (Nuth et al., 2007). However, at $-0.71 \pm 0.05 \mathrm{ma}^{-1}\left(-0.64 \pm 0.05 \mathrm{~m}\right.$ w.e. $\left.\mathrm{a}^{-1}\right)$ the average mass balance of glaciers in DL is among the most negative of the Svalbard regional means reported by Nuth et al. (2010) and Moholdt et al. (2010). Previously published occasional data from another region of central Spitsbergen, Nordenskiöld Land, show a generally similar glacier response to climate change and comparable mass balances to glaciers in DL (e.g. Troicki, 1988; Ziaja and Pipała, 2007; Bælum and Benn, 2011), indicating that observations from this study are valid for larger areas of the island's interior. Extrapolation of the mass balance from DL to glaciers in eastern DL-C and to neighbouring Nordenskiöld Land and Bünsow Land (Fig. 1a), comparable in terms of climate and glacier-cover characteristics, yields an estimate of the total mass balance of glaciers in central Spitsbergen. Despite their negligible share of the archipelago's ice area (ca. $800 \mathrm{~km}^{2}$ or $2 \%$ ), they contribute about $0.6 \mathrm{Gt} \mathrm{a}^{-1}$ to the sea-level rise, a figure comparable to the contribution of some of the much larger glacier regions, e.g. parts of southern or eastern Svalbard. The total mass balance of the archipelago has been estimated to range from $-4.3 \mathrm{Gt} \mathrm{a}^{-1}$ (Moholdt et al., 2010) to $-9.7 \mathrm{Gta}^{-1}$ (Nuth et al., 2010).

\section{Conclusions}

In this study, a multi-temporal inventory and DEMs of 152 small alpine glaciers and ice patches in Dickson Land, central Spitsbergen, were used to document their post-LIA evolution. In order to be in balance with the present climate, their ELA should be approximately $500 \mathrm{~m}$ a.s.l. However, due to progressive climate warming in Svalbard, the average ELA has increased and glaciers have been continuously losing mass for many decades. The total ice area in Dickson Land has been declining at an accelerating rate from $334.1 \pm 38.4 \mathrm{~km}^{2}$ at the termination of the LIA (early 20 th century) to $207.4 \pm 4.6 \mathrm{~km}^{2}$ in $2009 / 2011$, correspond- 
ing to an overall $38 \pm 12 \%$ decrease. Post-1990 area loss rate was 4.5 times higher than in the epoch LIA-1960s, i.e. $2.23 \pm 0.48 \mathrm{~km}^{2} \mathrm{a}^{-1}$ vs. $0.49 \pm 0.66 \mathrm{~km}^{2} \mathrm{a}^{-1}$ respectively. Front retreat of 66 test glaciers has accelerated over time, i.e. from an average of $4.9 \pm 0.1 \mathrm{~m} \mathrm{a}^{-1}$ in the period from the LIA maximum to the $1960 \mathrm{~s}$ and $9.4 \pm 0.1 \mathrm{~m} \mathrm{a}^{-1}$ between the 1960 s and 1990 to $16.4 \pm 0.1 \mathrm{~m} \mathrm{a}^{-1}$ in the last study epoch 1990-2009/2011, which turned out to be the period of the fastest retreat for $74 \%$ of glaciers.

The most important finding of this study is the recent rapid glacier-wide thinning over the entire region at a mean rate of $0.71 \pm 0.05 \mathrm{~m} \mathrm{a}^{-1}\left(-0.64 \pm 0.05 \mathrm{~m}\right.$ w.e. $\left.\mathrm{a}^{-1}\right)$. The warming climate has caused an ELA rise and a consequent increase in the zero-elevation change line, so local glaciers have been thinning up to the altitude of $1000 \mathrm{~m}$, i.e. higher than their accumulation zones. The spatial variability of glacier mass balance was primarily correlated with elevation, so small lowelevation glaciers have generally been losing mass and length at the fastest rates and are under threat of the earliest disappearance.

\section{The Supplement related to this article is available online at doi:10.5194/tc-10-1317-2016-supplement.}

Acknowledgements. The study is a contribution to the DIL*ICE project (Dickson Land Ice Masses Evolution, RiS id 4894) supported by the Polish National Science Centre (grant no. N306 062940) and the Institute of Geoecology and Geoinformation of Adam Mickiewicz University in Poznań. The author sincerely appreciates the support from Copernicus Publications and the open-access data policy of the Norwegian Polar Institute. Constructive reviews from P. Holmlund and J. Kohler helped to significantly improve the manuscript and are greatly appreciated. The comments on the early manuscript and handling of the manuscript by the editor J. O. Hagen are also acknowledged.

Edited by: J. O. Hagen

\section{References}

Bælum, K. and Benn, D. I.: Thermal structure and drainage system of a small valley glacier (Tellbreen, Svalbard), investigated by ground penetrating radar, The Cryosphere, 5, 139-149, doi:10.5194/tc-5-139-2011, 2011.

Błaszczyk, M., Jania, J., and Kolondra, L.: Fluctuations of tidewater glaciers in Hornsund Fjord (Southern Svalbard) since the beginning of the 20th century, Pol. Polar Res., 34, 327-352, 2013.

Cox, L. H. and March, R. S.: Comparison of geodetic and glaciological mass-balance techniques, Gulkana Glacier, Alaska, U.S.A., J. Glaciol., 50, 363-370, 2004.

Evans, D. J. A., Strzelecki, M., Milledge, D. G., and Orton, C.: Hørbyebreen polythermal glacial system, Svalbard, J. Maps, 8, 146$156,2012$.
Ewertowski, M.: Recent transformations in the high-Arctic glacier landsystem, Ragnarbreen, Svalbard, Geogr. Ann. A, 93, 265285, doi:10.1111/geoa.12049, 2014.

Ewertowski, M. and Tomczyk, A.: Quantifcation of the icecored moraines' short-term dynamics in the high-Arctic glaciers Ebbabreen and Ragnarbreen, Petuniabukta, Svalbard, Geomorphology, 234, 211-227, doi:10.1016/j.geomorph.2015.01.023, 2015.

Ewertowski, M., Kasprzak, L., Szuman, I., and Tomczyk, A. M.: Depositional processes within the frontal ice-cored moraine system, Ragnar glacier, Svalbard, Quaest. Geograph., 29, 27-36, 2010.

Ewertowski, M., Kasprzak, L., Szuman, I., and Tomczyk, A. M.: Controlled, ice-cored moraines: sediments and geomorphology. An example from Ragnarbreen, Svalbard, Z. Geomorphol., 51, 53-74, doi:10.1127/0372-8854/2011/0049, 2012.

Fischer, M., Huss, M., and Hoelzle, M.: Surface elevation and mass changes of all Swiss glaciers 1980-2010, The Cryosphere, 9, 525-540, doi:10.5194/tc-9-525-2015, 2015.

Førland, E. J., Benestad, R., Hanssen-Bauer, I., Haugen, J. E., and Skaugen, T. E.: Temperature and Precipitation Development at Svalbard 1900-2100, Adv. Meteorol., 2011, 893790, doi:10.1155/2011/893790, 2011.

Gardner, A. S., Moholdt, G., Wouters, B., Wolken, G. J., Burgess, D. O., Sharp, M. J., Cogley, J. G., Braun, C., and Labine, C.: Sharply increased mass loss from glaciers and ice caps in the Canadian Arctic Archipelago, Nature, 473, 357-360, 2011.

Gardner, A. S., Moholdt, G., Cogley, J. G., Wouters, B., Arendt, A. A., Wahr, J., Berthier, E., Hock, R., Pfeffer, W. T., Kaser, G., Ligtenberg, S. R. M., Bolch, T., Sharp, M. J., Hagen, J. O., van den Broecke, M. R., and Paul, F.: A reconciled estimate of glacier contributions to sea level rise: 2003 to 2009, Science, 340, 852 $857,2013$.

Gibas, J., Rachlewicz, G., and Szczuciński, W.: Application of DC resistivity soundings and geomorphological surveys in studies of modern Arctic glacier marginal zones, Petuniabukta, Spitsbergen, Pol. Polar Res., 26, 239-258, 2005.

Hagen, J. O., Liest $\varnothing 1$, O., Roland, E., and Jørgensen, T.: Glacier atlas of Svalbard and Jan Mayen, Oslo, Norwegian Polar Institute, 141 pp., 1993.

Hagen, J. O., Kohler, J., Melvold, K., and Winther, J.-G.: Glaciers in Svalbard: mass balance, runoff and freshwater flux, Polar Res., 22, 145-159, 2003.

Hodgkins, R., Hagen, J. O., and Hamran, S.-E.: 20th century mass balance and thermal regime change at Scott Turnerbreen, Svalbard, Ann. Glaciol., 28, 216-220, 1999.

IPCC: Climate Change 2013, The Physical Science Basis, Working Group I Contribution to the Fifth Assessment Report of the Intergovernmental Panel on Climate Change, WMO/UNEP, Cambridge University Press, Geneva, 2013.

James, T. D., Murray, T., Barrand, N. E., Sykes, H. J., Fox, A. J., and King, M. A.: Observations of enhanced thinning in the upper reaches of Svalbard glaciers, The Cryosphere, 6, 1369-1381, doi:10.5194/tc-6-1369-2012, 2012.

Jania, J.: Dynamiczne procesy glacjalne na południowym Spitsbergenie w świetle badań fotointerpretacyjnych i fotogrametrycznych (Dynamic glacial processes in south Spitsbergen in the light of photointerpretation and photogrammetry), Prace 
Naukowe Uniwersytetu Śląskiego, Katowice, ISBN 83-2260200-6, 1988.

Karczewski, A.: The development of the marginal zone of the Hørbyebreen, Petuniabukta, central Spitsbergen, Pol. Polar Res., 10, 371-377, 1989.

Kohler, J., James, T. D., Murray, T., Nuth, C., Brandt, O., Barrand, N. E., Aas, H. F., and Luckman, A.: Acceleration in thinning rate on western Svalbard glaciers. Geophys. Res. Lett., 34, L18502, doi:10.1029/2007GL030681, 2007.

Kostrzewski, A., Kaniecki, A., Kapuściński, J., Klimczak, R., Stach, A., and Zwoliński, Z.: The dynamics and rate of denudation of glaciated and non-glaciated catchments, central Spitsbergen, Pol. Polar Res., 10, 317-367, 1989.

König, M., Kohler, J. and Nuth, C.: Glacier Area Outlines - Svalbard, Norwegian Polar Institute (Troms $\varnothing$, Norway), https://data. npolar.no/dataset/89f430f8-862f-11e2-8036-005056ad0004, 2013.

Lang, C., Fettweis, X., and Erpicum, M.: Future climate and surface mass balance of Svalbard glaciers in an RCP8.5 climate scenario: a case study with the regional climate model MAR forced by MIROC5, The Cryosphere, 9, 945-956, doi:10.5194/tc-9-5452015, 2015.

Lankauf, K. R.: Recesja lodowców rejonu Kaffiøyry (Ziemia Oskara II - Spitsbergen) w XX wieku (Retreat of Kaffiøyra glaciers [Oscar II Land - Spitsbergen] in the 20th century), Prace Geograficzne nr. 183, Polska Akademia Nauk, Warszawa, 2002.

Láska, K., Witoszová, D., and Prošek, P.: Weather patterns of the coastal zone of Petuniabukta, central Spitsbergen in the period 2008-2010, Pol. Polar Res., 33, 297-318, 2012.

Li, Ya. and Li, Yi.: Topographic and geometric controls on glacier changes in the central Tien Shan, China, since the Little Ice Age, Ann. Glaciol., 55, 177-186, doi:10.3189/2014AoG66A031, 2014.

Lovell, H., Fleming, E. J., Benn, D. I., Hubbard, B., Lukas, S., and Naegeli, K.: Former dynamic behaviour of a cold-based valley glacier on Svalbard revealed by basal ice and structural glaciology investigations, J. Glaciol., 61, 309-328, 2015.

Małecki, J.: The present-day state of Svenbreen (Svalbard) and changes of its physical properties after the termination of the Little Ice Age. PhD thesis, Adam Mickiewicz University in Poznań, 145 pp., 2013a.

Małecki, J.: Elevation and volume changes of seven Dickson Land glaciers, Svalbard, Polar Res., 32, 18400, doi:10.3402/polar.v32i0.18400, 2013b.

Małecki, J.: Some comments on the flow velocity and thinning of Svenbreen, Dickson Land, Svalbard, Czech Polar Rep., 4, 1-8, 2014.

Małecki, J.: Snow accumulation on a small high-Arctic glacier Svenbreen - variability and topographic controls, Geogr. Ann. A., 97, 809-817, 2015.

Małecki, J., Faucherre, S., and Strzelecki, M.: Post-surge geometry and thermal structure of Hørbyebreen, central Spitsbergen, Pol. Polar Res., 34, 305-321, 2013.

Martín-Español, A., Navarro, F. J., Otero, J., Lapazaran, J. J., and Błaszczyk, M.: Estimate of the total volume of Svalbard glaciers, and their potential contribution to sea-level rise, using new regionally based scaling relationships, J. Glaciol., 61, 2941, doi:10.3189/2015JoG14J159, 2015.
Moholdt, G., Nuth, C., Hagen, J. O., and Kohler, J.: Recent elevation changes of Svalbard glaciers derived from ICESat laser altimetry, Remote Sens. Environ., 114, 2756-2767, 2010.

Nordli, Ø., Przybylak, R., Ogilvie, A. E. J., and Isaksen, K.: Longterm temperature trends and variability on Spitsbergen: the extended Svalbard Airport temperature series, 1898-2012, Polar Res., 33, 21348, doi:10.3402/polar.v33.21349, 2014.

Norwegian Polar Institute: Kartdata Svalbard 1:100 000 (S100 Kartdata). Troms $\emptyset$, Norway: Norwegian Polar Institute, https://data. npolar.no/dataset/645336c7-adfe-4d5a-978d-9426fe788ee3 (last access: 2 January 2015), 2014a.

Norwegian Polar Institute: Terrengmodell Svalbard (S0 Terrengmodell). Troms $\varnothing$, Norway: Norwegian Polar Institute, https:// data.npolar.no/dataset/dce53a47-c726-4845-85c3-a65b46fe2fea (last access: 3 March 2015), 2014b.

Nuth, C. and Kääb, A.: Co-registration and bias corrections of satellite elevation data sets for quantifying glacier thickness change, The Cryosphere, 5, 271-290, doi:10.5194/tc-5-271-2011, 2011.

Nuth, C., Kohler, J., Aas, H. F., Brandt, O., and Hagen, J. O.: Glacier geometry and elevation changes on Svalbard (1936-90): a baseline dataset. Ann. Glaciol., 46, 106-116, 2007.

Nuth, C., Moholdt, G., Kohler, J., Hagen, J. O., and Kääb, A.: Svalbard glacier elevation changes and contribution to sea level rise, J. Geophys. Res., 115, F01008, doi:10.1029/2008JF001223, 2010.

Nuth, C., Kohler, J., König, M., von Deschwanden, A., Hagen, J. O., Kääb, A., Moholdt, G., and Pettersson, R.: Decadal changes from a multi-temporal glacier inventory of Svalbard, The Cryosphere, 7, 1603-1621, doi:10.5194/tc-7-1603-2013, 2013.

Oerlemans, J.: Extracting a Climate Signal from 169 Glacier Records, Science, 308, 675-677, doi:10.1126/science.1107046, 2005.

Paul, F. and Mölg, N.: Hasty retreat of glaciers in northern Patagonia from 1985 to 2011, J. Glaciol., 60, 2014, doi:10.3189/2014JoG14J104, 2014.

Pleskot, K.: Sedimentological characteristics of debris flow deposits within ice-cored moraine of Ebbabreen, central Spitsbergen, Pol. Polar Res., 36, 125-144, 2015.

Pohjola, V. A., Martma, T., Meijer, H. A. J., Moore, J. C., Isaksson, E., Vaikmae, R., and van de Wal, R. S. W.: Reconstruction of three centuries of annual accumulation rates based on the record of stable isotopes of water from Lomonosovfonna, Svalbard, Ann. Glaciol., 35, 57-62, 2002.

Przybylak, R., Araźny, A., Nordli, Ø., Finkelnburg, R., Kejna, M., Budzik, T., Migała, K., Sikora, S., Puczko, D., Rymer, K., and Rachlewicz, G.: Spatial distribution of air temperature on Svalbard during 1 year with campaign measurements, Int. J. Climatol., 34, 3702-3719, doi:10.1002/joc.3937, 2014.

Rachlewicz, G.: River floods in glacier-covered catchments of the high Arctic: Billefjorden-Wijdefjorden, Svalbard, Norsk Geogr. Tidskr., 63, 115-122, 2009a.

Rachlewicz, G.: Contemporary sediment fluxes and relief changes in high Arctic glacierized valley systems (Billefjorden, Central Spitsbergen). Uniwersytet im. Adama Mickiewicza w Poznaniu, seria geografia nr 87. Poznań, Poland, Wydawnictwo Naukowe UAM, 2009b.

Rachlewicz, G. and Styszyńska, A.: Comparison of the course of air temperature in Petuniabukta and Svalbard-Lufthavn (Isfjord, 
Spitsbergen) in the years 2001-2003, Problemy Klimatologii Polarnej, 17, 121-134, 2007.

Rachlewicz, G., Szczuciński, W., and Ewertowski, M.: Post-"Little Ice Age" retreat rates of glaciers around Billefjorden in central Spitsbergen, Svalbard, Pol. Polar Res., 28, 159-186, 2007.

Radić, V. and Hock, R.: Regionally differentiated contribution of mountain glaciers and ice caps to future sea-level rise, Nat. Geosci., 4, 91-94, 2011.

Strzelecki, M. C., Małecki, J., and Zagórski, P.: The influence of recent deglaciation and associated sediment flux on the functioning of polar coastal zone - northern Petuniabukta, Svalbard, in: Sediment Fluxes in Coastal Areas. Coastal Research Library 10, edited by: Maanan, M. and Robin, M., Springer Science+Business Media, Dordrecht, 23-45, 2015 a.

Strzelecki, M. C., Long, A. J., and Lloyd, J. M.: Post-Little Ice Age development of a High Arctic paraglacial beach complex, Permafrost Periglac., doi:10.1002/ppp.1879, 2015 b.

Sobota, I.: Selected methods in mass balance estimation of Waldemar Glacier, Spitsbergen, Pol. Polar Res., 28, 249-268, 2007.

Szpikowski, J., Szpikowska, G., Zwoliński, Z., Rachlewicz, G., Kostrzewski, A., Marciniak, M., and Dragon, K.: Character and rate of denudation in a High Arctic glacierized catchment (Ebbaelva, Central Spitsbergen), Geomorphology, 218, 52-62, doi:10.1016/j.geomorph.2014.01.012, 2014.

Szczuciński, W., Zajączkowski, M., and Scholten, J.: Sediment accumulation rates in subpolar fjords - Impact of post-Little Ice Age glaciers retreat, Billefjorden, Svalbard, Estuar. Coast. Shelf S., 85, 345-356, 2009.
Troicki, L. S.: O balanse massy lednikov raznyh typov na Špicbergenie (On the mass balance of different types of glaciers on Spitsbergen), Materialy Glyaciologičeskih Issledovanij, 63, 117-121, 1988.

van Pelt, W. J. J., Oerlemans, J., Reijmer, C. H., Pohjola, V. A., Pettersson, R., and van Angelen, J. H.: Simulating melt, runoff and refreezing on Nordenskiöldbreen, Svalbard, using a coupled snow and energy balance model, The Cryosphere, 6, 641-659, doi:10.5194/tc-6-641-2012, 2012.

Willis, M. J., Melkonian, A. K., Pritchard, M. E., and Rivera, A.: Ice loss from the Southern Patagonian Ice Field, South America, between 2000 and 2012, Geophys. Res. Lett., 39, L17501, doi:10.1029/2012GL053136, 2012.

Zagórski, P., Siwek, K., Gluza, A., and Bartoszewski, S. A.: Changes in the extent and geometry of the Scott Glacier, Spitsbergen, Pol. Polar Res., 29, 163-185, 2008.

Ziaja, W.: Glacial recession in Sørkappland and central Nordenskiöldland, Spitsbergen, Svalbard, during the 20th century, Arct. Antarct. Alp. Res., 33, 36-41, 2001.

Ziaja, W. and Pipała, R.: Glacial recession 2001-2006 and its landscape effects in the Lindströmfjellet-Håbergnuten mountain ridge, Nordenskiöld Land, Spitsbergen, Pol. Polar Res., 28, 237 247, 2007.

Žuravlev, A. B., Mačeret, Ju. Ja., and Bobrova, L. I.: Radiolokalicjonnije issledovanije na poljarnom lednike s zimnym stokom (Radio-echo sounding investigations on a polar glacier with winter discharge), Materialy Glyaciologičeskih Issledovanij, 46, 143-149, 1983. 